https://doi.org/10.46344/JBINO.2021.v10i02.19

\title{
CORRELATION URINE SPECIFIC GRAVITY AND AFFINITY FOR GAMES
}

\author{
Muhammad Imran Qadir, Maheen Aslam, Fatima Afzal *. \\ Institute of Molecular Biology and Biotechnology. Bahauddin Zakariya University Multan. \\ (Received on Date: 15 December 2020 \\ Date of Acceptance: 1 March2021 \\ Date of Publish: 19 March 2021) \\ Email : fatimaafzaldnp993@gmail.com
}

\begin{abstract}
For the maintenance of our health games are essential. Some outside games are an organised and systematic form of the play. One of the big causes of mental ailment is not indulging us in different games. Urine specific gravity is the test to evaluate normal kidney functions. During the process of the urination different water soluble compounds are removed and the function of kidney is to produce concentrated urine to ensure the minimal loss of the water. The object of a study is to find a relationship between urine specific gravity of different people and their taste for games.
\end{abstract}




\section{INTRODUCTION}

For the maintenance of our health games are essential. Some outside games are an organised and systematic form of the play. One of the big causes of mental ailment is not indulging us in different games. One should be very cautious that he/she is going to play because playing games in front of the digital screen is a hug e threat for our mental disorders. Games, some indoors and outdoors, keep our body healthy and active. While playing games our spirit should be competitive. So for the children there is no better place than our play ground where they may engage themselves in different games. Among the various function of the kidney removal of the water soluble compound is also the function of kidney. Urine specific gravity is the test to evaluate normal kidney functions. During the process of the urination different water soluble compounds are removed and the function of kidney is to produce concentrated urine to ensure the minimal loss of the water. In adults the specific urine gravity is 1.01 to 1.03 . If urine specific gravity increase it means that more and more concentrated urine will produce and vice versa. If urine specific gravity increase or decrease from a certain limit then it cues to renal disorders.

The object of a study is to find a relationship between urine specific gravity of different people and their taste for games.

\section{Material and Method}

Almost 100 students participated in this study. All these were students of Bahaudin Zakariya University.

There are various test of urine for diagnose purpose. Urinalysis can be performed by using strip used for mostly urine test. The results of the test can be can be detected as a colour change. During the urine test first sample of urine was collected about 32 To 55 millimetre of each student. And urine specific gravity was checked.

\section{RESULTS AND DISCUSSION}

\section{Demonstration of Affinity for Outdoor Game/Indoor Game among Youth with Their Varying Urine Leucocytes level in Urine}

\begin{tabular}{|l|l|l|l|}
\hline \multicolumn{2}{|l|}{ Outdoor Games Likeness } & \multicolumn{2}{l|}{ Indoor Games Likeness } \\
\hline $\begin{array}{l}\text { Females urine } \\
\text { specific } \\
\text { gravit(mean } \pm \text { SD }\end{array}$ & $\begin{array}{l}\text { Females urine } \\
\text { specific } \\
\text { gravit(mean } \pm \text { SD }\end{array}$ & $\begin{array}{l}\text { Females urine } \\
\text { specific } \\
\text { gravit(mean } \pm \text { SD }\end{array}$ & $\begin{array}{l}\text { Females urine } \\
\text { specific } \\
\text { gravit(mean } \pm \text { SD }\end{array}$ \\
& ) & ) \\
\hline
\end{tabular}




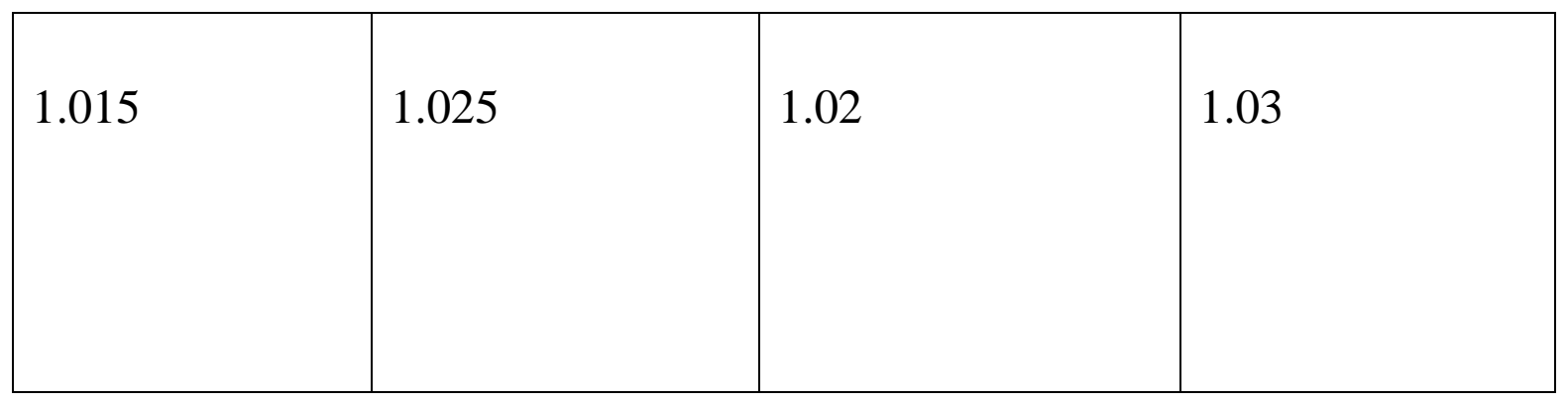

It is inferred from present study that those female with the average of urine specific gravity of 1.015 and males with 1.025 were more attracted toward outdoor games. And those female with the average of urine specific gravity of 1.02 and males with 1.0 w3ere more attracted toward indoor games.

\section{Conclusion}

There is little impact of urine specific gravity on likeness for games. 